\title{
Profil Terapi dan Efek Samping Anti Tuberkulosis pada Pasien AIDS Rawat Inap
}

\author{
Claudia Tiffany' ${ }^{1}$, Didik Hasmono' ${ }^{1}$, dan Agus Sunarko² \\ ${ }^{1}$ Departemen Farmasi Klinis, Fakultas Farmasi Universitas Airlangga, Surabaya, Indonesia \\ ${ }^{2}$ Instalasi Farmasi RSUD Dr. Saiful Anwar, Malang, Indonesia
}

Korespondensi: Claudia Tiffany

Email: claudiatiffany20@gmail.com

Submitted: 24-05-2019, Revised: 15-11-2019, Accepted: 03-12-2019

\begin{abstract}
ABSTRAK: AIDS adalah penyakit yang menjadi permasalahan global, termasuk Indonesia. Pasien AIDS mudah mengalami infeksi oportunistik, dimana salah satu yang berbahaya adalah TB paru. Pasien AIDS-TB menerima polifarmasi yang memerlukan perhatian khusus dari sisi kefarmasian untuk menjamin safety pasien. Tujuan dari penelitian ini adalah mengkaji pola penggunaan anti tuberkulosis pada pasien AIDS terkait jenis, rute, dan dosis, serta melihat efek samping selama penggunaan anti tuberkulosis. Penelitian ini adalah penelitian observasional dan retrospektif, menggunakan rekam medik pasien AIDS-TB paru yang mendapat terapi OAT dalam jangka waktu 1 Januari-31 Desember 2014. Penelitian ini dilaksanakan pada bulan April-Mei 2016 di RSUD dr. Saiful Anwar, Malang. Dari 36 rekam medik pasien AIDS dengan TB paru diketahui sebanyak 22 pasien (61\%) berada dalam fase intensif OAT kategori I, 8 pasien (22\%) dalam terapi fase intensif kategori II, 2 pasien $(6 \%)$ dalam fase lanjutan kategori I, 1 pasien (3\%) dalam fase intensif kategori I kemudian mendapatkan OAT kondisi khusus, 1 pasien (3\%) dalam fase intensif kategori II namun mengalami pergantian ke fase intensif MDR-TB, dan 1 pasien (3\%) mendapatkan fase intensif kondisi khusus. Problem terkait obat yang didapatkan pada penelitian ini adalah: terjadinya ruam (6\%), Steven Johnson Syndrome (3\%), gangguan fungsi liver (22\%), dan ikterus tanpa adanya penyebab lain (3\%).
\end{abstract}

Kata kunci: AIDS; anti tuberkulosis; paru; tuberkulosis

\begin{abstract}
AIDS is a global problem, including in Indonesia. AIDS patients are easy to get pulmonary tuberculosis. These patients will receive polypharmacy which require special attention to ensure patient safety. The objective of this study is to examine the usage patterns of anti-tuberculosis therapy in AIDS patients related to types, route, dose, and see whether there are any side effects during anti-tuberculosis use. This was observational and retrospective study using patient medical record, conducted at dr. Saiful Anwar hospital, Malang in the period of April-Mei 2016. Based on medical record of 36 AIDS patients with pulmonary TB, 22 patients (61\%) were in the intensive phase of treatment anti-tuberculosis cate-gory I, 8 patients (22\%) in the treatment of the intensive phase of category II, 2 patients (6\%) in the continuation phase category I, 1 patient (3\%) was in the intensive phase of category I then get a special conditions regimen of anti-tuberculosis therapy, 1 patient (3\%) was in the intensive phase category II but underwent a change to the intensive phase of MDR-TB, and other 1 patient (3\%) was get the intensive phase of special conditions. Drug related problems that identified were rash (6\%), Steven Johnson syndrome (3\%), drug induced hepatitis due to anti-tuberculosis (22\%), and jaundice without other cause (3\%).
\end{abstract}

Keywords: AIDS; anti tuberculosis; pulmonary; tuberculosis 


\section{Pendahuluan}

Human Immunodeficiency Virus (HIV) adalah virus yang menyebabkan penyakit Acquired Immune Deficiency Syndrome (AIDS). Virus ini termasuk dalam famili Human Retroviruses/Retroviridae, sub famili Lentivirus [1]. Terdapat dua jenis virus HIV, yakni HIV-1 dan HIV-2 [2]. Transmisi virus HIV dapat melalui beberapa cara, antara lain: penggunaan jarum suntik yang sama secara bergantian, transfusi darah yang telah tercemar virus HIV, hubungan heteroseksual, dan homoseksual, dan secara vertikal dari ibu ke anak (transmisi congenital) [3]. Bagian dari virus HIV yang memiliki peran awal untuk menginfeksi sel T CD4 manusia adalah Glikoprotein 120 (gp 120). Gp 120 dapat membentuk ikatan dengan reseptor CCR5 dan CXCR4 pada permukaan CD4 [4]. Ikatan yang terbentuk membuat terjadinya perubahan konformasi reseptor CD4 secara irreversible, yang kemudian diikuti oleh penetrasi materi genetik HIV dan mulailah tahapan replikasi dan infeksi HIV [5].

Peningkatan viral load dan penurunan CD4 menunjukkan progresivitas infeksi HIV. Terdapat 4 stadium infeksi HIV, pada stadium 1 cenderung asimptomatis, sedangkan stadium 4 merupakan stadium AIDS yang ditandai dengan terjadinya berbagai macam infeksi oportunistik dan jumlah CD4 $<200 \mathrm{sel} / \mu \mathrm{l}$ [6]. Salah satu infeksi oportunistik yang berbahaya dan dapat meningkatkan angka kematian pasien AIDS adalah TB paru. Penyakit infeksi yang disebabkan oleh Mycrobacterium tuberculosis ini ditularkan dari orang-orang yang terjangkit TB melalui batuk, atau bersin, yang menghasilkan "droplet nuclei" yang tersebar di udara. Infeksi dapat terjadi tergantung pada jumlah mikroorganisme yang dihirup, virulensi mikroorganisme, dan sistem imun dari pasien. Oleh karena itu orang yang terinfeksi HIV akan lebih mudah untuk terinfeksi TB. Hal ini ditunjukkan dari 183 kasus TB paru di Indonesia per 100.000 populasi tiap tahunnya, 3,2\% dari insiden TB tiap tahun terjadi pada penderita AIDS [7].

Pada prinsipnya regimentasi Obat Anti Tuber- kulosis (OAT) yang diberikan pada pasien AIDS sama dengan pasien TB non AIDS, perbedaannya adalah pasien AIDS juga mendapatkan terapi ARV, namun mendahulukan pengobatan TB untuk mengurangi angka kesakitan dan kematian $[8,9]$. Penggunaan obat antituberkulosis pada pasien AIDS perlu dilakukan monitoring secara intens, hal ini dikarenakan oleh: pasien AIDS berada dalam status immunocompromised ditandai dengan nilai CD4 yang rendah (seringkali $<200$ sel/ $\mu \mathrm{l})$, sehingga perkembangan bakteri Мyсоbacterium tuberculosis lebih pesat. Hal ini juga berperan dalam terjadinya resistensi anti tuberkulosis (selain faktor kepatuhan pasien) dan terjadi relaps [10].

OAT adalah obat dengan kemungkinan efek samping yang tinggi. Terjadinya peningkatan efek samping pada pasien AIDS dikarenakan overlapping ESO dengan obat lain. Contohnya pada penggunaan nevirapin dan rifampisin, isoniazid, ataupun pirazinamid yang dapat menyebabkan gangguan hepar [11]. Peningkatan efek samping juga dikarenakan oleh status immunocompromised pasien yang dapat meningkatkan terjadinya hipersensitivitas pada penggunaan OAT [12]. Oleh karena itu perlu dilakukan studi mengenai profil penggunaan OAT pada pasien AIDS yang dapat digunakan nantinya sebagai gambaran dalam monitoring penggunaan OAT, untuk mengetahui pola penggunaan OAT dan ada tidaknya efek samping yang terjadi selama terapi [13].

\section{Metode}

Penelitian ini adalah penelitian observasional dengan pengambilan data secara retrospektif, dilaksanakan di RSUD dr. Saiful Anwar Malang pada bulan April-Mei 2016. Sampel penelitian ini adalah rekam medik kesehatan pasien AIDS yang rawat inap di RSUD dr. Saiful Anwar Malang dan mendapatkan terapi OAT, selama periode 1 Januari-31 Desember 2014. Kriteria inklusi pada penelitian ini: semua pasien AIDS dewasa, rawat inap dengan diagnosa TB paru, dan mendapatkan 
terapi OAT pada periode waktu yang sudah ditentukan. Kriteria eksklusi pada penelitian ini meliputi: pasien meninggal dunia setelah menerima terapi OAT \pm 1 hari, sehingga tidak didapatkan profil penggunaan OAT; pasien AIDS-TB ekstra paru tanpa disertai adanya TB paru; pasien AIDS rawat jalan; pasien anak; pasien AIDS dengan diagnosa MDR-TB dari awal diagnosa.

Tahapan penelitian yang dilakukan adalah: (1) mendaftarkan penelitian pada bagian pendidikan dan penelitian RSUD dr. Saiful Anwar untuk memperoleh sertifikat kelaikan etik; (2) memperoleh rekam medik kesehatan (RMK) pasien dari bagian rekam medik; (3) mencatat data RMK ke lembar pengumpulan data (LPD); (4) membuat tabel induk; (5) melakukan rekapitulasi dan pengolahan data menggunakan Microsoft excel; (6) membuat bahasan mengenai profil terapi OAT dan menganalisa data. Analisa data yang dilakukan adalah analisa deskriptif dari demografi pasien, OAT yang sering digunakan dalam terapi pasien, regimen OAT, serta permasalahan yang mungkin terjadi terkait OAT (efek samping, kesesuaian pemilihan OAT, dan dosis OAT), dalam hal ini data terapi pasien dilihat kesesuaiannya dengan pedoman terapi tuberkulosis dari Kementrian Kesehatan RI maupun Perhimpunan Dokter Paru Indonesia (PDPI). Data-data dan hasil analisis yang diperoleh disajikan dalam bentuk tabel ataupun diagram.

\section{Hasil dan pembahasan}

Penelitian ini telah dinyatakan layak etik oleh komisi etik penelitian kesehatan RSUD dr. Saiful Anwar, ditunjukkan dengan surat kelaikan etik No. 400/38/K.3/302/2016. Dari penelitian ini didapatkan 64 pasien AIDS-TB paru yang rawat inap di RSUD dr. Saiful Anwar selama periode 1 Januari-31 Desember 2014. Dari 64 pasien tersebut didapatkan 36 pasien yang memenuhi kriteria inklusi dan eksklusi dan 28 pasien yang tereksklusi (Gambar 1), hal ini dikarenakan terjadi peningkatan SGOT dan SGPT hingga tiga kali lipat dari batas normal sebelum pasien memulai terapi OAT, pasien meninggal pada hari ke-dua masuk rumah sakit (MRS) sehingga tidak didapatkan profil terapi OAT, dan pasien meninggal dunia sebelum memulai terapi OAT.

Dari 36 RMK pasien yang terpilih tersebut, diketahui bahwa pasien AIDS-TB paru terbanyak adalah pria, yaitu sebanyak 22 pasien dengan persentase $60 \%$, dengan rentang umur tertinggi adalah 30-34 tahun sebanyak 14 pasien (39\%) (Gambar 2). Berdasarkan data sosial demografi pasien, diketahui bahwa tingkat pendidikan terbanyak adalah SMP (Gambar 3). Tingkat pendidikan dapat mempengaruhi tingkat pengetahuan seseorang. Melalui pendidikan diharapkan setiap orang memiliki pengetahuan yang lebih dan cara

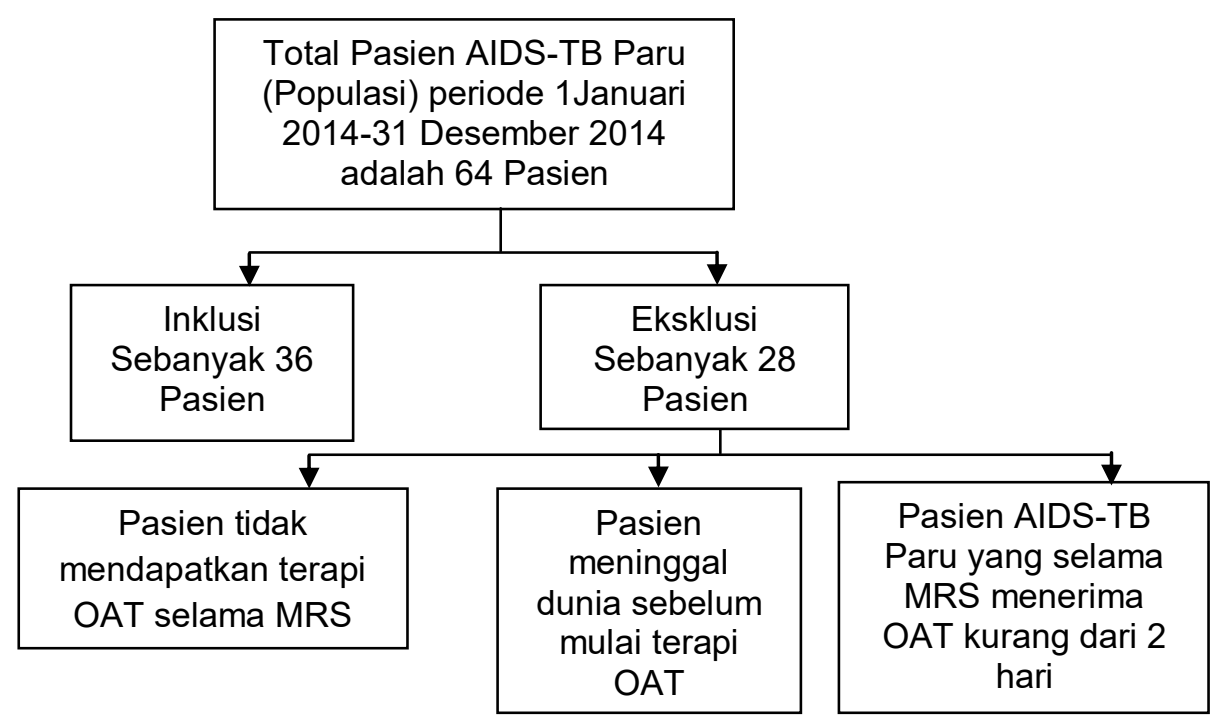

Gambar 1. Inklusi-eksklusi pasien AIDS-TB paru 


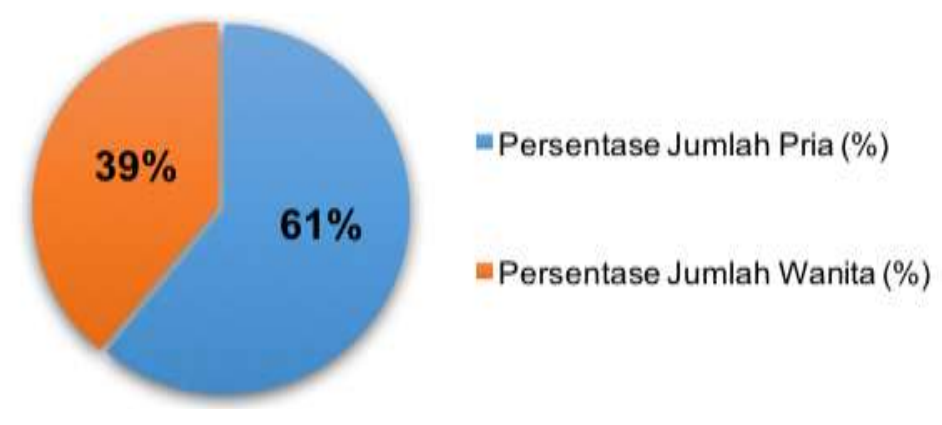

(a)

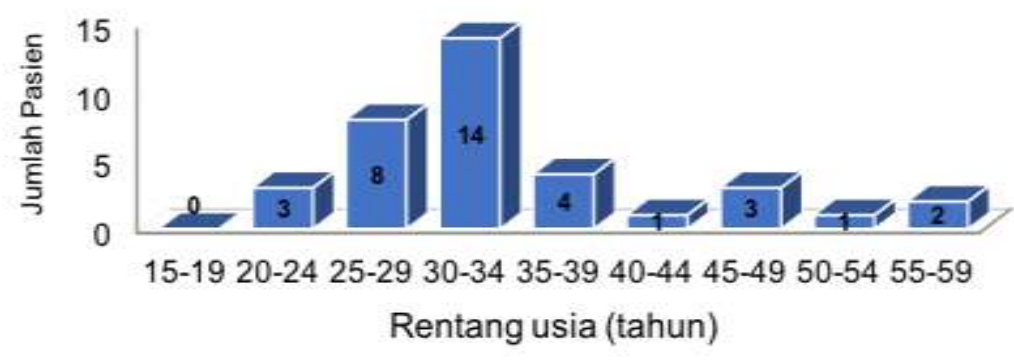

(b)

Gambar 2. Diagram distribusi jenis kelamin (a) dan usia (b) pasien HIV/AIDS-TB

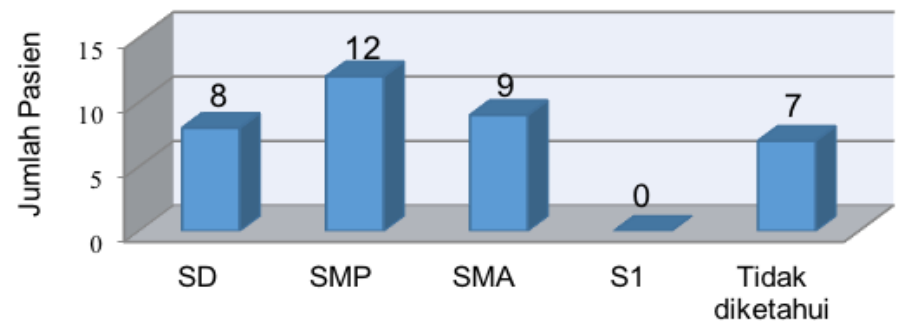

Gambar 3. Diagram distribusi tingkat pendidikan pasien HIV/AIDS-TB

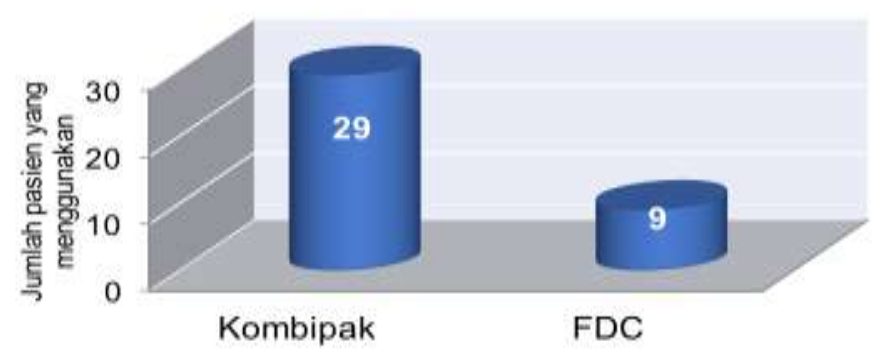

Gambar 4. Diagram distribusi jenis paket OAT 
berfikir yang lebih baik dan logis. Selain itu di bidang kesehatan tingkat pendidikan juga dapat mempengaruhi penyebaran penyakit [14]. Dengan tingkat pendidikan yang lebih baik diharapkan dapat mengurangi angka penyebaran penyakit, dikarenakan higienitas yang lebih baik dan juga masyarakat menjadi lebih memahami transmisi suatu penyakit, salah satunya adalah HIV yang dapat menyebabkan angka kematian tinggi pada penderitanya [15].

Terdapat 2 jenis tablet OAT yaitu kombipak dan OAT-KDT atau FDC. OAT paket kombipak adalah paket obat lepas yang terdiri dari isoniazid, rifampisin, pirazinamid, dan etambutol. Paket kombipak dapat merupakan pilihan yang tepat apabila terjadi efek samping pada penggunaan OAT-KDT sebelumnya. Sedangkan OAT-KDT merupakan paket kombinasi dosis tetap, dimana penggunaannya disesuaikan dengan berat badan pasien [16]. Berdasarkan data RMK serta hasil analisa terkait OAT yang diberikan pada pasien diketahui sebanyak 29 pasien menggunakan kombipak (Gambar 4) dan terdapat dua orang pasien yang mengalami pergantian dari yang awalnya menggunakan KDT menjadi kombipak, dan sebaliknya.

Setiap paket OAT baik KDT maupun kombipak memiliki kelebihan dan kekurangan masingmasing. Kelebihan dari KDT adalah dosis obat disesuaikan dengan berat badan sehingga efektifitas obat dapat terjamin, hal ini dikarenakan terjadinya kesalahan dalam peresepan lebih kecil, mengingat dosis diatur dengan berat badan. Kelebihan yang kedua adalah jumlah tablet yang harus diminum oleh pasien lebih sedikit sehingga dapat meningkatkan kepatuhan pasien, dan dapat mencegah resiko resistensi karena dalam satu tablet OAT KDT langsung terdapat 4 jenis OAT. Disamping semua kelebihan tersebut terdapat kekurangan KDT, antara lain: apabila terjadi kesalahan dalam peresepan maka dapat terjadi pemberian dosis OAT lebih dari dosis terapi untuk pasien tersebut, sehingga terdapat resiko toksisitas, atau dapat terjadi resistensi apabila dosis yang diberikan kepada pasien terlalu ren- dah. Penggunaan KDT juga dapat membuat petugas kesehatan yang bertugas mengawasi pasien minum obat menjadi lalai dikarenakan percaya bahwa penggunaan KDT akan meningkatkan kepatuhan pasien untuk meminum OAT, kelemahan yang lain adalah bioavailabilitas dari rifampisin yang menurun pada beberapa KDT (tidak semua KDT oleh dari itu harus diuji bioavailabilitas dari masing-masing OAT dalam tablet KDT tersebut). Sementara itu, kelebihan dari kombipak adalah lebih mudah dalam pengaturan dosis untuk masing-masing jenis OAT, karena kombipak merupakan paket OAT lepas ( 1 tablet 1 jenis OAT), kombipak juga merupakan paket pilihan apabila pasien terbukti mengalami efek samping pada terapi menggunakan KDT OAT. Kekurangan dari paket kombipak adalah pada jumlah obat lebih besar yang harus diminum oleh pasien, sehingga dapat menurunkan kepatuhan, selain itu juga memungkinkan terjadi kesalahan yang lebih besar dalam peresepan [16, 17].

Pergantian jenis OAT kombipak menjadi OATKDT pada pasien sesuai dengan pedoman terapi tuberkulosis yaitu untuk meningkatkan kepatuhan pasien, karena jumlah obat yang diminum lebih sedikit. Pada pergantian OAT-KDT menjadi kombipak, tidak ditemukan kondisi kontraindikasi untuk pasien menerima OAT-KDT, sehingga sebaiknya pasien tetap mendapatkan OAT-KDT $[8,18]$.

Lama pengobatan TB paru pada penderita HIV maupun non HIV adalah sama, yaitu 6 bulan. Enam bulan tersebut terdiri dari 2 bulan fase intensif dan 4 bulan fase lanjutan, selain itu terdapat 2 kategori pengobatan dalam penelitian ini, yaitu kategori I yang digunakan untuk TB paru BTA positif maupun negatif dengan lesi luas, dan kategori II untuk pasien kambuh, gagal pengobatan, putus obat atau lost to follow up. Perbedaan antara kategori I dan kategori II terletak pada lama terapi dan terdapat tambahan obat injeksi yaitu streptomisin pada fase intensif dan etambutol pada fase lanjutan [18,19]. Namun baik pada kategori I maupun II masih tetap menggunakan OAT lini pertama yaitu rifampisin 
(R), isoniazid (H), pirazinamid (Z), etambutol (E), streptomisin (S). Jenis OAT tersebut dipilih sebagai lini pertama karena memiliki potensi yang besar untuk membunuh maupun menghambat pertumbuhan Mycobacterium tuberculosis. Terdapat 3 sifat utama dari obat antituberkulosis, antara lain: aktivitas bakterisidal, kemampuan sterilisasi (sterilizing activity), dan kemampuan untuk mencegah terjadinya resistensi. Tiga sifat utama ini dimiliki oleh lini pertama OAT. Rifampisin dan isoniazid adalah OAT yang memiliki kemampuan bakterisidal yang paling besar, serta aktif terhadap semua populasi/ jenis TB bacilli. Selain itu rifampisin juga mempunyai kemampuan sterilisasi yang poten [16]. OAT lain yang juga memiliki kemampuan sterilisasi adalah pirazinamid. Pirazinamid mempunyai kemampuan sterilisasi, mampu berpenetrasi secara efisien kedalam lokasi infeksi Mycobacterium tuberculosis pada lesi paru, hal ini dikarenakan pirazinamid akan diubah menjadi asam pirazinat oleh enzim pyrazinamidase yang berasal dari basil TB [20]. Selain rifampisin, isoniazid, dan pirazinamid, OAT yang juga bersifat bakterisidal adalah streptomisin. Streptomisin digunakan pada regimen OAT kategori II dengan rute pemakaian secara intra muscular. OAT lini pertama yang terakhir adalah etambutol. Etambutol bersifat bakteriostatik, diperlukan kombinasi dengan OAT lain yang bersifat bakterisidal untuk mencegah resistensi dari basil TB $[8,16]$.

Dalam hal pemilihan kategori OAT, terdapat 5 pasien yang mengalami permasalahan (Tabel 2), diantaranya terdapat pasien yang diduga kambuh (pasien memiliki riwayat TB paru beberapa tahun sebelum 2014 dan dari hasil foto thorax serta diagnosa dokter diketahui TB paru positif) namun pada saat MRS diberikan OAT fase intensif kategori I. Pemilihan OAT yang sesuai untuk kasus tersebut adalah OAT kategori II, dimana

Tabel 1. Jenis, rute, dan dosis OAT kombipak fase intensif

\begin{tabular}{|c|c|c|c|}
\hline Jenis dan rute OAT & Dosis (mg) & Dosis (pustaka) & Jumlah pasien \\
\hline \multirow[t]{5}{*}{ Rifampisin (PO) } & $1 \times 150$ & \multirow{5}{*}{$\begin{array}{l}\text { Dosis harian }(\mathrm{mg}) / \mathrm{BB}(\mathrm{kg}): \mathrm{BB}<40 \mathrm{~kg}=300 \\
\mathrm{mg} ; 40-60 \mathrm{~kg}=450 \mathrm{mg} ;>60 \mathrm{~kg}=600 \mathrm{mg}[18]\end{array}$} & 1 \\
\hline & $1 \times 300$ & & 4 \\
\hline & $1 \times 400$ & & 1 \\
\hline & $1 \times 450$ & & 17 \\
\hline & $1 \times 600$ & & 3 \\
\hline \multirow[t]{5}{*}{ Isoniazid (PO) } & $1 \times 200$ & \multirow{5}{*}{$\begin{array}{l}\text { Dosis harian }(\mathrm{mg}) / \mathrm{BB}(\mathrm{kg}): \mathrm{BB}<40 \mathrm{~kg}=150 \\
\mathrm{mg} ; 40-60 \mathrm{~kg}=300 \mathrm{mg} ;>60 \mathrm{~kg}=450 \mathrm{mg}[18]\end{array}$} & 2 \\
\hline & $1 \times 300$ & & 23 \\
\hline & $1 \times 400$ & & 1 \\
\hline & $1 \times 500$ & & 1 \\
\hline & $1 \times 600$ & & 1 \\
\hline \multirow[t]{3}{*}{ Pirazinamid (PO) } & $1 \times 750$ & \multirow{3}{*}{$\begin{array}{l}\text { Dosis harian }(\mathrm{mg}) / \mathrm{BB}(\mathrm{kg}) \text { : } \mathrm{BB}<40 \mathrm{~kg}=750 \\
\mathrm{mg} ; 40-60 \mathrm{~kg}=1000 \mathrm{mg} ;>60 \mathrm{~kg}=1500 \mathrm{mg} \\
{[18]}\end{array}$} & 7 \\
\hline & $1 \times 1000$ & & 20 \\
\hline & $1 \times 1500$ & & 2 \\
\hline \multirow{4}{*}{ Etambutol (PO) } & $1 \times 500$ & \multirow{4}{*}{$\begin{array}{l}\text { Dosis harian }(\mathrm{mg}) / \mathrm{BB}(\mathrm{kg}): \mathrm{BB}<40 \mathrm{~kg}=750 \\
\mathrm{mg} ; 40-60 \mathrm{~kg}=1000 \mathrm{mg} ;>60 \mathrm{~kg}=1500 \mathrm{mg} \\
{[18]}\end{array}$} & 2 \\
\hline & $1 \times 750$ & & 15 \\
\hline & $1 \times 800$ & & 2 \\
\hline & $1 \times 1000$ & & 11 \\
\hline \multirow[t]{4}{*}{ Streptomisin (IM) } & $1 \times 500$ & \multirow{4}{*}{$\begin{array}{l}\text { Dosis harian }(\mathrm{mg}) / \mathrm{BB}(\mathrm{kg}): \mathrm{BB}<40 \mathrm{~kg}=\text { sesuai } \\
\mathrm{BB} ; 40-60 \mathrm{~kg}=750 \mathrm{mg} ;>60 \mathrm{~kg}=1000 \mathrm{mg}[18]\end{array}$} & 3 \\
\hline & $1 \times 600$ & & 1 \\
\hline & $1 \times 750$ & & 4 \\
\hline & $1 \times 1000$ & & 2 \\
\hline
\end{tabular}


terdapat penambahan streptomisin IM pada regimen OAT $[8,18]$. Selain itu terdapat pasien yang berobat kembali setelah drop-out OAT. Pada MRS pertama OAT kategori I fase intensif dilanjutkan kembali, dan saat MRS ke-2 terapi OAT memasuki fase lanjutan kategori I namun didapatkan hasil BTA positif, foto thorax TB paru positif. Rekomendasi OAT untuk pasien ini adalah OAT fase intensif kategori II, hal ini sesuai dengan penatalaksanaan OAT untuk pasien AIDS-TB paru yang dropout OAT, hasil BTA positif namun tidak didapati resistensi terhadap OAT lini pertama, foto thorax TB paru positif, dan akan melakukan pengobatan ulang [20]. Sebaliknya terdapat seorang pasien yang baru terdiagnosa TB paru dan menerima OAT fase intensif kategori I selama 20 hari, na- mun pada saat MRS diberikan OAT fase intensif kategori II. Rekomendasi OAT untuk pasien ini sebaiknya adalah melanjutkan OAT fase intensif kategori I yang telah diterima pasien sebelumnya [8].

Profil penggunaan OAT terkait jenis, rute pemberian, dan dosis OAT terdapat pada Tabel 1-Tabel 5. Tabel 1 menampilkan jenis OAT, rute, dan dosis pemberian pada fase intensif, baik kategori I maupun kategori II. Pasien yang menggunakan OAT-KDT akan menerima tablet 4KDT, dimana 1 tablet mengandung 4 jenis OAT (R/H/Z/E). Dosis yang diterima oleh pasien berbeda-beda tergantung pada berat badan. Terdapat 7 pasien dalam pengobatan fase intensif kategori I yang mendapatkan tablet 4KDT. Diantaranya terdapat

Tabel 2. Distribusi fase terapi OAT pasien AIDS

\begin{tabular}{|c|c|c|c|c|}
\hline \multicolumn{2}{|c|}{ Fase terapi OAT } & \multirow{2}{*}{$\begin{array}{l}\text { OAT yang } \\
\text { diberikan } \\
\mathrm{R}, \mathrm{H}, \mathrm{Z}, \mathrm{E}\end{array}$} & \multirow{2}{*}{$\begin{array}{l}\text { Jumlah } \\
\text { pasien } \\
22\end{array}$} & \multirow{2}{*}{$\begin{array}{l}\text { Keterangan } \\
\text { Terdapat } 2 \text { pasien yang } \\
\text { mengalami permasalahan } \\
\text { terkait pemilihan kategori } \\
\text { OAT }\end{array}$} \\
\hline Fase intensif & Fase intensif kategori I & & & \\
\hline & $\begin{array}{l}\text { Fase intensif kategori I, } \\
\text { kemudian beralih ke } \\
\text { intensif kondisi khusus }\end{array}$ & R, H, Z, E; E, S, Lfx & 1 & $\begin{array}{l}\text { Pasien relaps dan mengalami } \\
\text { ESO OAT peningkatan } \\
\text { bilirubin }>2 \mathrm{x} \text { normal, yaitu } \\
2,92 \mathrm{mg} / \mathrm{dL}\end{array}$ \\
\hline & Fase intensif kategori II & $\mathrm{R}, \mathrm{H}, \mathrm{Z}, \mathrm{E}, \mathrm{S}$ & 8 & $\begin{array}{l}\text { Terdapat } 1 \text { pasien yang } \\
\text { mengalami permasalahan } \\
\text { terkait pemilihan kategori } \\
\text { OAT }\end{array}$ \\
\hline & $\begin{array}{l}\text { Fase intensif kondisi } \\
\text { khusus }\end{array}$ & $\begin{array}{l}\text { E, S (MRS 1); R, H, E } \\
\text { (MRS 2) }\end{array}$ & 1 & Pemilihan OAT tepat \\
\hline & $\begin{array}{l}\text { Fase intensif kategori II, } \\
\text { kemudian beralih ke } \\
\text { fase intensif MDR-TB }\end{array}$ & $\begin{array}{l}\mathrm{R}, \mathrm{H}, \mathrm{Z}, \mathrm{E}, \mathrm{S} ; \mathrm{E}, \mathrm{Z} \\
\mathrm{Km}, \mathrm{Lfx}, \mathrm{Cs}, \text { Eto }\end{array}$ & 1 & $\begin{array}{l}\text { Pasien menerima OAT } \\
\text { kategori I namun setelah hasil } \\
\text { mikrobiologi dan gene Xpert } \\
\text { keluar diketahui resisten } \\
\text { rifampisin, sehingga regimen } \\
\text { OAT diganti dengan OAT MDR }\end{array}$ \\
\hline Total pasien & & & 33 & \\
\hline \multirow[t]{2}{*}{ Fase lanjutan } & $\begin{array}{l}\text { Fase lanjutan kategori I } \\
\text { (juga didapatkan data } \\
\text { profil penggunaan OAT } \\
\text { fase intensif kategori I } \\
\text { saat pasien MRS } \\
\text { pertama) }\end{array}$ & $\mathrm{R}, \mathrm{H}, \mathrm{Z}, \mathrm{E} ; \mathrm{R}, \mathrm{H}$ & 1 & $\begin{array}{l}\text { Pasien mengalami } \\
\text { permasalahan terkait } \\
\text { pemilihan kategori OAT }\end{array}$ \\
\hline & $\begin{array}{l}\text { Fase Lanjutan kategori I } \\
\text { (Pasien saat MRS sudah } \\
\text { dalam terapi fase } \\
\text { lanjutan OAT) }\end{array}$ & $\mathrm{R}, \mathrm{H}$ & 2 & Pemilihan OAT tepat \\
\hline Total pasien & & & 3 & \\
\hline
\end{tabular}


Tabel 3. Jenis, rute, dan dosis OAT kombipak fase lanjutan

\begin{tabular}{llll}
\hline Jenis dan rute OAT & Dosis (mg) & Dosis (pustaka) & Jumlah pasien \\
\hline Rifampisin (PO) & $1 \times 450$ & Dosis harian: $10 \mathrm{mg} / \mathrm{kgBB}$; Kisaran dosis & \\
& & harian: 8-12 mg/kgBB; Dosis maksimum/hari: & 1 \\
& & $600 \mathrm{mg}[8]$ & \\
\hline Isoniazid (PO) & $1 \times 300$ & $\begin{array}{l}\text { Dosis harian: } 10 \mathrm{mg} / \mathrm{kgBB} \text {; Kisaran dosis } \\
\text { harian: 8-12 mg/kgBB; Dosis maksimum/hari: }\end{array}$ & \\
& & $600 \mathrm{mg}[8]$ & \\
\hline
\end{tabular}

Tabel 4. Jenis, rute, dan dosis OAT KDT fase intensif

\begin{tabular}{|c|c|c|c|c|}
\hline $\begin{array}{l}\text { Kategori } \\
\text { KDT }\end{array}$ & $\begin{array}{l}\text { Tahap intensif RHZE (150 } \\
\mathrm{mg} / 75 \mathrm{mg} / 400 \mathrm{mg} / 275 \mathrm{mg})\end{array}$ & $\begin{array}{l}\text { Jumlah } \\
\text { pasien }\end{array}$ & Keterangan & $\begin{array}{l}\text { Dosis tahap intensif } \\
\text { (4KDT) (pustaka) }\end{array}$ \\
\hline \multirow[t]{3}{*}{ 4KDT Kat I } & $\begin{array}{l}\text { Pergantian dari } 1 \text { tablet } 4 \mathrm{KDT} \\
\text { menjadi } 3 \text { tablet } 4 \mathrm{KDT}\end{array}$ & 1 & $\begin{array}{l}\text { Pergantian } \\
\text { dikarenakan terjadi } \\
\text { ketidaksesuaian } \\
\text { dosis dengan BB (BB } \\
\text { pasien } 50 \mathrm{~kg} \text { ) }\end{array}$ & $\begin{array}{l}\text { BB } 30-37 \text { kg: } 2 \text { tablet; } \\
38-54 \text { kg: } 3 \text { tablet; } 55- \\
70 \text { kg: } 4 \text { tablet; } \geq 71 \mathrm{~kg}: \\
5 \text { tablet [8] }\end{array}$ \\
\hline & 4 tablet 4 KDT & 3 & & \\
\hline & 3 tablet $4 \mathrm{KDT}$ & 3 & & \\
\hline
\end{tabular}

Tabel 5. Jenis, rute, dan dosis OAT KDT fase lanjutan

\begin{tabular}{llll}
\hline $\begin{array}{l}\text { Kategori } \\
\text { KDT }\end{array}$ & Tahap lanjutan RH (150 $\mathbf{~ m g / 1 5 0 ~} \mathbf{~ m g})$ & $\begin{array}{l}\text { Jumlah } \\
\text { pasien }\end{array}$ & $\begin{array}{l}\text { Dosis tahap lanjutan (2KDT) } \\
\text { (pustaka) }\end{array}$ \\
\hline 2KDT Kat I & 1 tablet 2KDT & 1 & $\begin{array}{l}\text { BB 30-37 kg: } 2 \text { tablet; } 38-54 \mathrm{~kg}: 3 \\
\text { tablet; } 55-70 \mathrm{~kg}: 4 \text { tablet; } \geq 71 \mathrm{~kg}:\end{array}$ \\
& 3 tablet 2KDT & 1 & 5 tablet [8]
\end{tabular}

1 orang pasien yang mengalami permasalahan terkait dosis. Pasien dengan berat badan $50 \mathrm{~kg}$ awal MRS mendapatkan dosis 1x 4KDT (1 tablet), pada hari ke-3 MRS, dosis 4KDT ditingkatkan menjadi 3 tablet/hari. Dalam hal ini pasien dengan berat badan $50 \mathrm{~kg}$ dosis $4 \mathrm{KDT}$ yang direkomendasikan adalah 3 tablet/hari [8, 18]. Pemberian tablet 4KDT yang tidak sesuai dengan rekomendasi dosis dapat beresiko meningkatkan resistensi, ditambah status immunocompromised yang dialami pasien. Apabila diperlukan penyesuaian dosis terkait kondisi pasien, dapat digunakan tablet kombipak. Hal ini dikarenakan, rentang dosis kombipak dapat lebih luas. Untuk masing-masing OAT terdapat dosis (mg) minimal hingga maksimal yang disesuaikan dengan berat badan pasien per hari $[8,18,21]$. Sebagai contoh pasien TSS status HIV (+), keluhan batuk memberat 8 sebelum MRS, demam, dan keri- ngat malam, nafsu makan menurun, tes sputum sewaktu-pagi-sewaktu (SPS) menunjukkan BTA (+). Pasien dengan berat badan $50 \mathrm{~kg}$, mendapatkan terapi OAT fase intensif kombipak dengan dosis R/H/Z/E (450/300/1000/1000). Rentang dosis untuk masing-masing OAT antara lain: $\mathrm{R}$ adalah 8-12 mg/KgBB/hari dengan dosis maksimal $600 \mathrm{mg}$, H (4-6 mg/KgBB/hari dengan dosis maksimal $300 \mathrm{mg}$ ), Z (20-30 mg/KgBB/hari), dan E (15-20 mg/KgBB/hari). Sehingga dapat diketahui bahwa dosis OAT yang didapatakan pasien sudah sesuai $[8,18]$.

Selain fase intensif kategori I dari hasil penelitian didapatkan 10 orang dalam pengobatan fase intensif kategori II. Semua pasien mendapatkan tablet kombipak disertai injeksi streptomycin (IM). Penggunaan kombipak pada pasien lebih menguntungkan untuk pengaturan dosis masing-masing obat sesuai dengan kondisi pasien, 
Tabel 6. Efek samping aktual penggunaan OAT

\begin{tabular}{|c|c|c|c|}
\hline Efek samping & Penyebab & Penatalaksanaan & Frekuensi \\
\hline $\begin{array}{l}\text { Bercak kemerahan pada } \\
\text { kulit (Rash) disertai } \\
\text { rasa gatal }\end{array}$ & $\mathrm{H}, \mathrm{R}, \mathrm{Z}, \mathrm{S}$ & $\begin{array}{l}\text { Diberi antihistamin, dilakukan drug challenging, } \\
\text { setelah rash dapat diatasi dilakukan desensitisasi } \\
\text { OAT dimulai dari H/R dengan dosis } 50 \text { mg, dosis } \\
\text { OAT tersebut ditingkatkan dalam waktu } 3 \text { hari. } \\
\text { Apabila tidak timbul reaksi dapat ditambahkan } 1 \\
\text { jenis OAT lagi. Jika muncul reaksi setelah } \\
\text { pemberian OAT tertentu maka terapi dapat } \\
\text { dilanjutkan tanpa pemberian OAT tersebut. }\end{array}$ & $2(6 \%)$ \\
\hline Gangguan fungsi liver & \multirow[t]{2}{*}{$\mathrm{H}, \mathrm{R}, \mathrm{Z}$} & \multirow[b]{2}{*}{$\begin{array}{l}\text { - Bila klinis (+) (ikterus (+), gejala mual, muntah } \\
(+) \text { ): OAT Stop. } \\
\text { - Bila gejala (+), dan SGOT, SGPT } \geq 3 X \text { : OAT Stop } \\
\text { hingga fungsi liver kembali normal atau } \\
\text { mendekati normal, mulai desensitisasi OAT. } \\
\text { - Bila gejala klinis (-), hasil abnormal: } \\
\text { - Bilirubin >2x atau SGOT, SGPT } \geq 5 x \text { : R, H, Z } \\
\text { stop, dapat diberikan kombinasi etambutol } \\
\text { dan streptomisin sambil menunggu fungsi } \\
\text { liver membaik. Bila fungsi liver kembali } \\
\text { normal atau mendekati normal, dapat } \\
\text { diberikan R dengan dosis bertahap, diikuti } \\
\text { dengan H } \\
\text { - SGOT, SGPT } \geq 3 x \text { : diteruskan pengobatan } \\
\text { dengan pengawasan. } \\
\text {-Pada TB berat + gangguan fungsi liver dapat } \\
\text { diberikan S, E, + } 1 \text { golongan fluorokuinolon. }\end{array}$} & $8(22 \%)$ \\
\hline $\begin{array}{l}\text { Ikterus tanpa penyebab } \\
\text { lain }\end{array}$ & & & $1(3 \%)$ \\
\hline $\begin{array}{l}\text { Steven Johnson } \\
\text { Syndrome }\end{array}$ & $\mathrm{H}, \mathrm{R}, \mathrm{Z}, \mathrm{S}$ & $\begin{array}{l}\text { Stop OAT, diberikan terapi kortikosteroid, } \\
\text { antihistamin (dalam pengawasan dokter), saat lesi } \\
\text { kulit telah membaik dapat dilakukan desensitisasi } \\
\text { OAT. }\end{array}$ & $1(3 \%)$ \\
\hline Tidak ada efek samping & & & $24(67 \%)$ \\
\hline
\end{tabular}

sehingga diharapkan akan meminimalkan efek samping yang terjadi namun tetap dapat menjaga efektivitas obat (dosis obat tetap dalam rentang terapi) $[16,17]$. Setelah fase intensif, pasien akan memasuki fase lanjutan. Pada fase lanjutan OAT yang didapatkan oleh pasien adalah $\mathrm{R}$ dan $\mathrm{H}$. Namun pada fase lanjutan kategori II terdapat penambahan E (dalam penelitian ini tidak didapatkan pasien pada fase lanjutan kategori II). Dari penelitian ini didapatkan 8 pasien dalam fase lanjutan kategori I, dimana 7 pasien mendapatkan tablet kombipak dan 1 pasien mendapatkan tablet 2KDT. Terdapat perbedaan fase lanjutan antara pasien TB dengan atau tanpa AIDS. Pada pasien AIDS fase lanjutan OAT harus diminum setiap hari (berlaku juga untuk tablet KDT) sama seperti fase intensif, hal ini dikarenakan kemungkinan terjadinya kekambuhan yang tinggi pasien AIDS [21].
Selain itu pada penelitian ini terdapat 2 pasien yang menerima OAT kondisi khusus, hal ini dikarenakan pasien tersebut mengalami efek samping OAT yaitu gangguan fungsi liver. Alasan pemberian OAT kondisi khusus adalah pasien mengalami infeksi TB yang berat, berdasarkan hasil foto thorax pada paru-paru kanan dan kiri pasien terdapat fibroinfiltrat pada keseluruhan area dan terdapat fibroinfiltrat yang tebal serta multiple cavities diameter 0,2-0,3 cm. Hasil radiologi tersebut menunjukkan bahwa pasien mengalami TB paru dengan lesi luas (Lung TB far advanced lesion). Pada pasien lainnya hasil radiologi menunjukkan bahwa pada pulmo dextra maupun sinistra terdapat infiltrat millier pada keseluruhan area dan air bronchogram (+), sehingga pasien terdiagnosa TB milier. Pada kondisi infeksi seperti ini ditambah dengan rendahnya imunitas pasien, maka tidak memungkinkan bila 
Tabel 7. Desensitisasi OAT

\begin{tabular}{|c|c|c|c|c|c|c|c|c|c|c|c|c|c|}
\hline \multirow{2}{*}{$\begin{array}{l}\text { Inisial } \\
\text { pasien }\end{array}$} & \multirow{2}{*}{$\begin{array}{l}\text { Nama } \\
\text { obat }\end{array}$} & \multicolumn{12}{|c|}{ Dosis (mg) dan frekuensi } \\
\hline & & 1 & 2 & 3 & 4 & 5 & 6 & 7 & 8 & 9 & 10 & 11 & 12 \\
\hline \multirow[t]{5}{*}{ S } & $\mathrm{H}$ & $1 \times 50$ & $1 \times 150$ & $1 \times 300$ & $1 \times 300$ & $1 \times 300$ & $1 \times 300$ & $1 \times 300$ & $1 \times 300$ & $1 \times 300$ & $1 \times 300$ & $1 \times 300$ & $1 \times 300$ \\
\hline & $\mathrm{R}$ & - & - & - & $1 \times 75$ & $1 \times 300$ & $1 \times 600$ & $1 \times 600$ & $1 \times 600$ & $1 \times 600$ & $1 \times 600$ & $1 \times 600$ & $1 \times 600$ \\
\hline & $\mathrm{Z}$ & - & - & - & - & - & - & $1 \times 250$ & $1 \times 1000$ & $1 \times 1500$ & $1 \times 1500$ & $1 \times 1500$ & $1 \times 1500$ \\
\hline & E & - & - & - & - & - & - & - & - & - & $1 \times 100$ & $1 \times 500$ & $1 \times 1500$ \\
\hline & S & - & - & - & - & - & - & - & - & - & - & $1 \times 250$ & $1 \times 750$ \\
\hline \multirow[t]{4}{*}{ BK } & $\mathrm{H}$ & $1 \times 50$ & $1 \times 150$ & $1 \times 300$ & $1 \times 300$ & $1 \times 300$ & $1 \times 300$ & $1 \times 300$ & $1 \times 300$ & $1 \times 300$ & $1 \times 300$ & $1 \times 300$ & $1 \times 300$ \\
\hline & $\mathrm{R}$ & - & - & - & $1 \times 75$ & $1 \times 300$ & $1 \times 600$ & $1 \times 600$ & $1 \times 600$ & $1 \times 600$ & $1 \times 600$ & $1 \times 600$ & $1 \times 600$ \\
\hline & $\mathrm{Z}$ & - & - & - & - & - & - & $1 \times 250$ & $1 \times 1000$ & $1 \times 1500$ & $1 \times 1500$ & $1 \times 1500$ & $1 \times 1500$ \\
\hline & $\mathrm{E}$ & - & - & - & - & - & - & - & - & - & $1 \times 250$ & $1 \times 1000$ & $1 \times 1500$ \\
\hline \multirow[t]{3}{*}{$\mathrm{FU}$} & $\mathrm{H}$ & $1 \times 100$ & $1 \times 200$ & $1 \times 200$ & $1 \times 300$ & $1 \times 300$ & - & - & - & - & - & - & - \\
\hline & $\mathrm{R}$ & $1 \times 200$ & $1 \times 200$ & $1 \times 200$ & $1 \times 200$ & $1 \times 400$ & - & - & - & - & - & - & - \\
\hline & $\mathrm{E}$ & $1 \times 200$ & $1 \times 200$ & $1 \times 200$ & $1 \times 200$ & $1 \times 300$ & - & - & - & - & - & - & - \\
\hline
\end{tabular}

dilakukan penghentian terapi OAT, sehingga digunakan OAT kondisi khusus yang terdiri dari etambutol (E) dan streptomisin (S), ditambah dengan satu golongan fluorokuinolon namun bukan ciprofloxasin karena potensi bakterisidal terhadap $M$. tuberculosis sangat lemah. Apabila hasil SGOT, SGPT, dan bilirubin telah kembali normal, maka pengobatan OAT semula dapat kembali satu persatu dengan dilakukan re-challenge $[8,18]$. Selain 2 pasien tersebut terdapat 10 pasien lain yang mengalami efek samping OAT (Tabel 6).

Pasien yang mengalami efek samping Steven Johnson Syndrome dan rash akan mengalami proses desensitisasi OAT seperti yang dapat dilihat pada Tabel 7, desensitisasi juga dapat dilakukan pada pasien yang mengalami drug induced liver injury (DILI) karena OAT, namun dosis inisiasi yang diberikan dapat berbeda. Contoh pasien yang mengalami desensitisasi karena DILI adalah FU. Pada pasien S dan BK, dengan berat badan 55 kg direkomendasikan dosis akhir pirazinamid (Z) adalah 1000 mg [8, 18]. Dosis pirazinamid yang tidak sesuai dapat menyebabkan terjadinya relaps DILI [22].

Pada penelitian ini tidak ditemukan adanya interaksi aktual yang terjadi pada pasien, dikarenakan penelitian ini dilakukan secara retrospektif, sehingga data tentang pasien juga terbatas, namun perlu diperhatikan OAT yang berkemungkinan besar menimbulkan interaksi adalah rifampisin dan isoniazid. Hal tersebut dikarenakan rifampisin bersifat auto-inducer dan inducer bagi obat-obat yang memiliki tempat metabolisme yang sama dengan rifampisin, yaitu CYP3A4. Sedangkan isoniazid merupakan inhibitor sitokrom P450 pada isoenzim CYP2C19, CYP3A4, CYP2A6, CYP2E1, dan CYP1A2 [23, 24].

Secara keseluruhan terapi yang diberikan kepada pasien sudah optimal, hal ini terlihat dari status KRS pasien AIDS-TB paru dimana dari 81\% pasien yang hidup diketahui $75 \%$ KRS dengan kondisi membaik.

\section{Kesimpulan}

Dari penelitian yang telah dilakukan, diketahui paket OAT yang digunakan adalah kombipak (29 pasien) dan OAT-KDT ( 9 pasien), kategori terapi dan fase terapi terbanyak adalah kategori I (69\%) dan fase intensif 22 pasien. Penggunaan kombinasi OAT yang banyak digunakan adalah RHZE (61\%). Permasalahan terkait OAT yang didapatkan antara lain dalam hal pemilihan kategori OAT (5 pasien) dan dosis (1 pasien), serta terjadinya efek samping yang disebabkan oleh penggunaan OAT yaitu ruam (2 pasien), Steven Johnson Syndrome (1 pasien), gangguan fungsi liver (8 pasien), dan ikterus (1 pasien).

\section{References}

1. German Advisory Committee Blood. Human Immunodeficiency Virus (HIV). Transfusion Medicine and Hemotherapy. 2016;43(3):203-22. 
2. Campbell-Yesufu O, Gandhi R. Update on Human Immunodeficiency Virus (HIV)-2 Infection. Clinical Infectious Diseases. 2011;52(6):780-7.

3. Public Health Agency of Canada. HIV transmission risk. Ottawa: Public Health Agency of Canada; 2012.

4. Robbins S, Cotran R. Pathologic Basis of Disease. 7th ed. Philadelphia: Elsevier inc; 2015.

5. Simon V, Ho D, Abdool Karim Q. HIV/AIDS epidemiology, pathogenesis, prevention, and treatment. The Lancet. 2006;368(9534):489-504.

6. World Health Organization. Interim WHO Clinical Staging of AIDS and AIDS Case Definitions for Surveillance. Geneva: WHO; 2005.

7. World Health Organization. Global Tuberculosis Report 2014. Geneva: WHO; 2014.

8. Kementrian Kesehatan Republik Indonesia (Kemenkes). Pedoman Nasional Pengendalian Tuberkulosis. Jakarta: Kemenkes RI; 2015.

9. Tabarsi P, Saber-Tehrani AS, Baghaei P, Padyab M, Mansouri D, Amiri M, Masjedi MR, Altice FL. Early initiation of antiretroviral therapy results in decreased morbidity and mortality among patients with TB and HIV. Journal of the International AIDS Society. 2009;12(1):14.

10. Gupta R, Lawn S, Bekker L, Caldwell J, Kaplan R, Wood R. Impact of human immunodeficiency virus and CD4 count on tuberculosis diagnosis: analysis of city-wide data from Cape Town, South Africa. The International Journal of Tuberculosis and Lung Disease. 2013;17(8):1014-22.

11. Drug/Drug Interactions [Internet]. Bhiva.org. 2015 [cited 23 September 2019]. Available from: http:// www.bhiva.org/50drugdruginteractionssee.aspx

12. Minhajat R, Djaharuddin I, Halim R, Benyamin A, Bakri S. Drugs Hypersensitivity Reaction in Patient with Human Immunodeficiency Virus (HIV) Infection. Journal of Allergy \& Therapy. 2017;8(1).

13. Dooley K, Flexner C, Andrade A. Drug Interactions Involving Combination Antiretroviral Therapy and Other Anti-Infective Agents: Repercussions for Resource-Limited Countries. The Journal of Infectious Diseases. 2008;198(7):948-61.

14. Institute of Medicine. Informing the future: Critical Issues in Health. 2nd ed. Washington, D.C.:
Institute of Medicine of the National Academies; 2003.

15. Kementrian Kesehatan Republik Indonesia (Kemenkes). Terobosan Menuju Akses Universal Strategi Nasional Pengendalian TB di Indonesia 2010-2014. Jakarta: Kementrian Kesehatan Republik Indonesia; 2014.

16. World Health Organization. Treatment of Tuberculosis: Guidelines for National Programmes. 3rd ed. Geneva: WHO; 2003.

17. Mathew J. Fixed-Dose Drug Combination for Treatment of Tuberculosis. Indian J Pediatrics. 2009;46(10):877-80.

18. Perhimpunan Dokter Paru Indonesia (PDPI). Tuberkulosis: Pedoman Diagnosis \& Penatalaksanaan di Indonesia [Internet]. Klikpdpi.com. 2006 [cited 23 September 2019]. Available from: http://www.klikpdpi.com/konsensus/tb/tb.html.

19. Rockwood N, du Bruyn E, Morris T, Wilkinson R. Assessment of treatment response in tuberculosis. Expert Review of Respiratory Medicine. 2016;10(6):643-54.

20. Prideaux B, Via LE, Zimmerman MD, Eum S, Sarathy J, O'brien P, Chen C, Kaya F, Weiner DM, Chen PY, Song T. The association between sterilizing activity and drug distribution into tuberculosis lesions. Nature medicine. 2015;21(10):1223-7.

21. World Health Organization. Treatment of Tuberculosis. 4th ed. Geneva: WHO; 2010.

22. Abbara A, Chitty S, Roe JK, Ghani R, Collin SM, Ritchie A, Kon OM, Dzvova J, Davidson H, Edwards TE, Hateley C. Drug-induced liver injury from antituberculous treatment: a retrospective study from a large TB centre in the UK. BMC Infectious Diseases. 2017;17(1):231.

23. Centers for Disease Control and Prevention (CDC). Managing Drug Interactions in the Treatment of HIV-Related Tuberculosis | Introduction | TB | CDC [Internet]. Cdc.gov. 2013 [cited 23 September 2019]. Available from: https://www.cdc.gov/tb/ publications/guidelines/tb_hiv_drugs/introduction.htm

24. Lacy C, Armstrong L, Goldman M, Lance L. Drug Information Handbook. 17th ed. Ohio: Lexi-Comp; 2009. 